\title{
Mitochondrial COI and morphological evidence for host specificity of the black cherry aphids Myzus cerasi (Fabricius, 1775) collected from different cherry tree species in Europe (Hemiptera,Aphididae)
}

\author{
Rimantas Rakauskas', Jekaterina Havelka', Audrius Zaremba', Rasa Bernotiené' \\ I Department of Zoology, Vilnius University, M. K. Ciurlionio 21/27, LT-03101, Vilnius, Lithuania \\ Corresponding author: Rimantas Rakauskas (rimantas.rakauskas@gf.vu.lt)
}

Academic editor: R. Blackman | Received 14 January 2014 | Accepted 26 February 2014 | Published 12 March 2014

Citation: Rakauskas R, Havelka J, Zaremba A, Bernotienè R (2014) Mitochondrial COI and morphological evidence for host specificity of the black cherry aphids Myzus cerasi (Fabricius, 1775) collected from different cherry tree species in Europe (Hemiptera, Aphididae). ZooKeys 388: 1-16. doi: 10.3897/zookeys.388.7034

\begin{abstract}
Partial sequences of the mitochondrial COI gene of forty eight European and two Turkish population samples of Myzus cerasi from different winter hosts (Prunus spp.) were subjected to phylogenetic analyses. The analysed $M$. cerasi samples emerged as paraphyletic relative to a Myzus borealis sample used as an outgroup, and formed two major clades in neighbor joining, maximum parsimony, maximum likelihood and Bayesian inference trees, corresponding to subspecies living specifically on Prunus avium and P. cerasus. Multivariate discriminant analysis (method of canonical variates) was applied to find out if morphological variation of samples correlated with mitochondrial COI and host plant information. Mean scores on the first two canonical variables clustered samples fully in accordance with their COI haplotypes and host plants confirming the existence of two morphologically similar winter host - specific subspecies of M. cerasi in Europe. No single morphological character enabled satisfactory discrimination between apterous viviparous females of the two subspecies. A three-character linear discriminant function enabled $92.37 \%$ correct identification of apterous viviparous females of $M$. cerasi cerasi $(\mathrm{n}=118)$ and $93.64 \%$ of $M$. cerasi pruniavium $(\mathrm{n}=110)$. A key for the morphological identification of the two subspecies is presented and their taxonomic status is discussed.
\end{abstract}

\section{Keywords}

Molecular systematics, cherry aphids, morphological key to subspecies

Copyright Rimantas Rakauskas et al. This is an open access article distributed under the terms of the Creative Commons Attribution International License (CC BY 4.0), which permits unrestricted use, distribution, and reproduction in any medium, provided the original author and source are credited. 


\section{Introduction}

Black cherry aphid Myzus cerasi (Fabricius, 1775) is reported to be a serious pest of cherries all over the world (Barbagallo et al. 1997, Blackman and Eastop 2000, Holman 2009) and its morphology, life cycle, host specificity and potential harmfulness have therefore been the subject of intensive studies (Ross 1918, Wimshurst 1925, Pokrovskyj 1932, Vereshchagina 1966, Fomicheva 1967, Karczewska 1970, Rakauskas 1984, Gruppe 1990, Cichocka and Goszczynski 2004). Nevertheless, the species level classification of black cherry aphids has not been satisfactorily resolved. The black shiny aphids inhabiting cherry trees were originally described as a single species, Myzus cerasi (Fabricius, 1775), but European populations inhabiting sweet cherry (Prunus avium) were later separated as Myzus pruniavium Börner, 1926. Börner's species has been accepted by some (Börner 1943, 1952, Heinze 1961), but synonymised with cerasi by others (Miyazaki 1971, Eastop and Hille Ris Lambers 1976, Remaudière and Remaudière 1997), while others have treated it as a subspecies of cerasi (Shaposhnikov 1972, Favret 2014). Differences in host specificity of the two taxa have been documented in experimental transfer studies (Karczewska 1970, Dahl 1968, Vereshchagina 1966), showing M. cerasi cerasi as heteroecious, alternating between cherries (both Prunus cerasus and P. avium) and herbaceous hosts (Galium, Euphrasia, Odontites, Veronica). M. cerasi pruniavium Börner, 1926 differs from the nominative subspecies in having $P$. avium as the only winter host (it is incapable of living on $P$. cerasus), and also has a somewhat different summer host list. Enzyme electrophoretic studies indicated a reduced gene exchange between the subspecies (Gruppe 1988a), perhaps due to differences in the phloem sap of sour and sweet cherry causing divergent selection (Gruppe 1989). Morphological characters for discrimination between the two taxa have been suggested (Heinze 1961), but none of these enabled satisfactory separation between viviparous females of $M$. c. cerasi and M. c. pruniavium when applied to independent aphid material (Dahl 1968, Gruppe 1988b). The taxonomic status of the black cherry aphid in the western Palaearctic thus remains unclear (Blackman and Eastop 2000, 2006, Lampel and Meier 2007, Holman 2009, Osiadacz and Halaj 2010). They are possibly members of a complex of cryptic aphid species that includes $M$. cerasi umefoliae (Shinji, 1924), which overwinters on P. mume in Japan with Artemisia as its summer host (Miyazaki 1971). In northern Europe there is also another potentially distinct taxon that lives all year without host alternation on herbaceous plants (Dahl 1968), and to which the name M. cerasi veronicae (Walker, 1848) may be applicable.

A similar species complex is found in the mealy plum aphid, Hyalopterus spp. (Lozier et al. 2008). Separation of three Hyalopterus species was eventually justified by their distinctness at molecular level (Lozier et al. 2008), but they still remain difficult to separate by their morphological characters (Basky and Szalay-Marszó 1987, Blackman and Eastop 1994, 2000, 2006), including those used in the most recent identification keys (Lozier et al. 2008, Rakauskas et al. 2013). A similar recent case is that of birch- and oak-inhabiting aphid species of the genus Stomaphis Walker, 1870 (Depa et al. 2012). 
The $M$. cerasi complex has not yet been the subject of detailed molecular study, although certain DNA sequences have been isolated (Foottit et al. 2008, Valenzuela et al. 2007, Clements et al. 2000, 2000a). Preliminary data on the partial sequences of the mitochondrial COI gene support the existence of subspecies of M. cerasi (Voronova et al. 2011). The aim of this study was to clarify the taxonomic status of the host-alternating taxa in the $M$. cerasi complex by a combined study of partial sequences of the mitochondrial COI gene and morphological characters of the European samples collected from different species of cherries.

\section{Material and methods}

\section{Material studied}

Fifty population samples of apterous viviparae of black cherry aphids from nine European countries and Turkey were collected in 2004-2013, mostly from $P$. cerasus, $P$. avium, but also from three other Prunus species (Table 1). Twenty samples were used for morphology - based stepwise discriminant analysis. The remaining 30 samples were used for subsequent evaluation of the derived discrimination functions. Samples of Myzus borealis Ossiannilsson, 1959 and Myzus persicae (Sulzer, 1776) (GenBank Accession No AB506741) were used as out-groups for the phylogenetic analyses.

\section{DNA extraction, PCR amplification and sequencing}

For molecular analysis, a single aphid individual from one sampled plant was considered as a unique sample. Total genomic DNA was extracted from a single aphid using the DNeasy Blood \& Tissue kit (Qiagen), which involved at least a $2 \mathrm{~h}$ digestion of tissue with proteinase K. Partial sequences of mitochondrial COI gene were PCRamplified using earlier published primers (Turčinavičienè et al. 2006). PCR amplification was carried out in a thermal cycler (Eppendorf) in $50 \mu \mathrm{l}$ volumes containing $2 \mu \mathrm{l}$ genomic DNA, $5 \mu \mathrm{l}$ of each primer $(10 \mu \mathrm{M}), 5 \mu \mathrm{l}$ of PCR-reaction buffer, $5 \mu \mathrm{l}$ of dNTP mix (2mM each), $4-8 \mu \mathrm{l}$ of $25 \mathrm{mM} \mathrm{MgCl}_{2}$ and $1.25 \mathrm{U}$ of AmpliTaq Gold 360 polymerase $(5 \mathrm{U} / \mu \mathrm{l})$ and $\mathrm{ddH}_{2} \mathrm{O}$ to $50 \mu \mathrm{l}$. The cycling parameters were as follows: denaturizing at $95^{\circ} \mathrm{C}$ for $10 \mathrm{~min}(1 \mathrm{cycle})$, denaturizing at $95^{\circ} \mathrm{C}$ for 30 ", annealing at $49{ }^{\circ} \mathrm{C}$ for $30^{\prime \prime}$ and extension at $72{ }^{\circ} \mathrm{C}$ for $30^{\prime \prime}$ (37 cycles in total), and a final extension for $5 \mathrm{~min}$ (1 cycle). PCR products were subjected to electrophoresis on $2 \%$ TopVision agarose (Fermentas, Lithuania), stained with GelRed and sized against a MassRuler Low Range DNA ladder (Fermentas, Lithuania) under UV light. PCR products were purified and sequenced at Macrogen Europe (Amsterdam, the Netherlands) and Institute of Biotechnology of the Vilnius University (Vilnius, Lithuania). The amplification primers were also used as sequencing primers. DNA sequences for each specimen were confirmed with both sense and anti-sense strands and aligned in 
Table I. Aphid material used in the present study. Samples used for morphology-based discriminant analysis are given in bold.

\begin{tabular}{|c|c|}
\hline Place, date, collection number; (number of individual apterae per sample) & GenBank Accession No \\
\hline \multicolumn{2}{|l|}{ Myzus cerasi on Prunus cerasus $\mathrm{L}}$. \\
\hline Jieznas, Prienai distr., Lithuania, 2012.05.30, 12-25; (8) & KF754311 \\
\hline Alytus, Lithuania, 2012.05.30, 12-30; (8) & KF754310 \\
\hline Daugai, Alytus distr., Lithuania, 2012.05.30, 12-32; (8) & KF754303 \\
\hline Skirgiškès, Vilnius distr., Lithuania, 2012.06.05, 12-37; (8) & KF754304 \\
\hline Eišiškès, Šalčininkai distr., Lithuania, 2012.06.13, 12-43; (7) & KF754329 \\
\hline Labanoras, Švenčionys distr., Lithuania, 2012.06.19, 12-70; (8) & KF754306 \\
\hline Molètai, Lithuania, 2012.06.19, 12-72; (8) & KF754314 \\
\hline Kraujaliai, Molètai distr., Lithuania, 2012.07.10, 12-120; (8) & KF754305 \\
\hline Žičkai, Molètai distr., Lithuania, 2012.07.13, 12-132; (8) & KF754321 \\
\hline Nida, Neringa, Lithuania, 2012.08.09, 12-176; (8) & KF754322 \\
\hline Smiltynè, Klaipèda, Lithuania, 2012.08.12, 12-191; (8) & KF754309 \\
\hline Preila, Neringa, Lithuania, 2012.08.13, 12-203; (8) & KF754330 \\
\hline Bagnolo Mella, Brescia prov., Italy, 2013.05.01, 13-27; (8) & KF754338 \\
\hline Poncarale, Brescia prov., Italy, 2013.05.02, 13-33; (8) & KF754337 \\
\hline Suginčiai, Molètai distr., Lithuania, 2013.06.15, 13-83; (8) & KF754345 \\
\hline Akmeniai, Lazdijai distr., Lithuania, 2013.05.30, 13-57; (8) & KF754341 \\
\hline Karsava, Ludza distr., Latvia, 2013.07.17, 13-133; (8) & KF754344 \\
\hline Gorodok, Vitebsk distr., Belarus, 2008.06.17, 08-6; (6) & KF754302 \\
\hline Zadrachje, Vitebsk distr., Belarus, 2008.06.18, 08-18; (8) & KF754325 \\
\hline Riga, Latvia, 2008.07.03, 08-73; (8) & KF754328 \\
\hline Skirgiškès, Vilnius distr., Lithuania, 2011.06.15, 11-46; (8) & KF754316 \\
\hline Cluj Gilau, Romania, 2012.06.19, Z12-112; (8) & KF754327 \\
\hline Cluj Gilau, Romania, 2012.06.19, Z12-116; (8) & KF754319 \\
\hline Poncarale, Brescia prov., Italy, 2013.05.02, 13-30; (8) & KF754346 \\
\hline Mezöpeterd, Hajdu-Bihar distr., Hungary, 2012.06.20, Z12-122; (8) & KF754333 \\
\hline
\end{tabular}

Myzus cerasi on Prunus avium $\mathrm{L}$.

Skirgiškès, Vilnius distr., Lithuania, 2012.06.05, 12-39; (7) $\quad$ KF754332

\begin{tabular}{l|l}
\hline Šalčininkai, Lithuania, 2012.06.13, 12-48; (6) & KF754317
\end{tabular}

\begin{tabular}{|l|l}
\hline Bratoniškès, Vilnius distr., Lithuania, 2012.06.14, 12-56; (7) & KF754313
\end{tabular}

\begin{tabular}{|c|c}
\hline Blagoevgrad, Bulgaria, 2012.06.26, 12-83; (7) & KF754318 \\
\hline
\end{tabular}

Frankfurt/Main, Germany, 2012.06.30, 12-104; (8)

\begin{tabular}{|l|l}
\hline Kraujaliai, Molètai distr., Lithuania, 2012.07.10, 12-111; (8) & KF754308
\end{tabular}

\begin{tabular}{|l|l}
\hline Stirniai, Molètai distr., Lithuania, 2012.07.12, 12-128; (8) & KF754320
\end{tabular}

\begin{tabular}{l|l}
\hline Juodkrantė, Neringa, Lithuania, 2012.08.10, 12-182; (8) & KF754323
\end{tabular}

\begin{tabular}{|c|c} 
Pervalka, Neringa, Lithuania, 2012.08.11, 12-188; (7) & KF754336
\end{tabular}

\begin{tabular}{l|l}
\hline Preila, Neringa, Lithuania, 2012.08.13, 12-199; (7) & KF754335 \\
\hline
\end{tabular}

\begin{tabular}{l|l}
\hline Rondo, Katowice, Poland, 2011.05.13, 11-10; (8) & KF754349
\end{tabular}

\begin{tabular}{|l|l}
\hline Tekir, Karamanmarash distr., Turkey, 2011.05.21, 11-25; (5) & KF754312 \\
\hline
\end{tabular}

\begin{tabular}{l|l}
\hline Göksun, Karamanmarash distr., Turkey, 2011.05.21, 11-27; (8) & KF754315
\end{tabular}

\begin{tabular}{l|l}
\hline Kairènai, Vilnius, Lithuania, 2010.07.01, 10-3; (7) & KF754324
\end{tabular}

\begin{tabular}{l|l}
\hline Zafferana, Catania, Italy, 2004.06.28, 04-49; (5) & KF754339
\end{tabular}

\begin{tabular}{l|l}
\hline Costinesti, Romania, 2012.06.15, Z12-90; (8) & KF754326
\end{tabular}

\begin{tabular}{l|l}
\hline Galata, Varna, Bulgaria, 2012.06.18, Z12-102; (7) & KF754351
\end{tabular}

\begin{tabular}{|c|c}
\hline Burgas, Bulgaria, 2012.06.19, Z12-110; (8) & KF754331
\end{tabular}

\begin{tabular}{l|l}
\hline Cluj Gilau, Romania, 2012.06.19, Z12-117; (7) & KF747679
\end{tabular} 


\begin{tabular}{|c|c|}
\hline Place, date, collection number; (number of individual apterae per sample) & GenBank Accession No \\
\hline Carpendolo, Brescia prov., Italy, 2013.04.27, 13-12; (7) & KF754340 \\
\hline Akmeniai, Lazdijai distr., Lithuania, 2013.05.30, 13-60; (8) & KF754347 \\
\hline Wojslawice, Lower Silesia, Poland, 2013.06.20, 13-98; (8) & KF754342 \\
\hline \multicolumn{2}{|l|}{ Myzus cerasi on Prunus serrulata Lindl. } \\
\hline Wojslawice, Lower Silesia, Poland, 2013.06.20, 13-97; (8) & KF754348 \\
\hline \multicolumn{2}{|l|}{ Myzus cerasi on Prunus maackii Rupr. } \\
\hline Dobele, Latvia, 2013.07.03, 13-119; (8) & KF754343 \\
\hline \multicolumn{2}{|l|}{ Myzus cerasi on Prunus mabaleb L. } \\
\hline Medias, Sibiu distr., Romania, 2012.06.19, Z12-113; (8) & KF754334 \\
\hline \multicolumn{2}{|l|}{ Myzus borealis on Galium rubioides $\mathrm{L}}$. \\
\hline Zmejinyje ostrova, Kanev distr., Cherkasy reg., Ukraine, 2006.06.16, 06-74 & KF754350 \\
\hline
\end{tabular}

the BioEdit Sequence Alignment Editor (Hall 1999). Partial sequences were tested for stop codons and none were found. The sequence data have been submitted to the GenBank, accession numbers are given in Table 1.

\section{Analysis of DNA sequences}

In addition to the sequences from 50 samples of $M$. cerasi, COI sequences of $M$. borealis from subgenus Myzus sensu stricto (the same subgenus as $M$. cerasi) and $M$. persicae from subgenus Nectarosiphon Schouteden, 1901 were selected as out-groups for the phylogenetic analyses, which included neighbor joining (NJ), maximum parsimony (MP), maximum likelihood (ML) and Bayesian inference in phylogeny (BI). NJ, MP and ML analyses were performed using MEGA 5 (Tamura et al. 2011). For NJ analysis Kimura 2-parameter (K2P) model of base substitution was used. Bootstrap values for NJ, MP and ML trees were generated from 1000 replicates. For ML analysis Tamura 3-parameter model with Gamma distribution $(\mathrm{T} 92+\mathrm{G})$ was selected by MEGA 5 model selection option (Tamura et al. 2011). Bayesian analysis was conducted in MrBayes 3.2.1 (Ronquist and Huelsenbeck 2003) using Hasegawa-Kishino-Yano model with Invariable sites and Gamma distribution $(\mathrm{HKY}+\mathrm{I}+\mathrm{G})$, which was selected by jModeltest (Posada 2008). Four simultaneous chains, 3 heated and 1 "cold", were run for 3000 000 generations with tree sampling every 1000 generations. The topologies obtained by $\mathrm{NJ}, \mathrm{MP}, \mathrm{ML}$ and BI were similar, so only ML tree is shown with values of NJ/MP and ML/BI bootstrap support and posterior probabilities over 50\% indicated above and below branches respectively. Statistical parsimony haplotype networks were constructed for samples of M. cerasi and M. borealis using TCS v 1.21 (Clement et al. 2000).

\section{Morphological study and discrimination analysis}

Samples representing different clades in the molecular tree and haplotype network were used for stepwise discriminant analysis followed by canonical analysis: $10 \mathrm{sam}$ - 
ples from sour cherry, $P$. cerasus, and 10 samples from sweet cherry, $P$. avium (shown in bold in Table 1).

Based on earlier taxonomic work (Heinze 1961, Dahl 1968), 19 metric (in mm) characters were studied: A2L - length of antennal segment 2; A3L - length of antennal segment 3; A4L - length of antennal segment 4; A5L - length of antennal segment 5; A6BL - length of basal part of antennal segment 6; A6TPL - length of terminal process of antennal segment 6; BL - body length (excluding cauda); Bwant 3 - basal width of antennal segment 3; CL - length of cauda; CW - basal width of cauda; DT3L - length of the second segment of hind tarsus; F3L - length of hind femur; FF - depth of the frontal furrow; SL - length of siphunculus; T3L - length of hind tibia; URL length of ultimate rostral segment; URW - basal width of ultimate rostral segment; VBSLmax - maximal length of the ventral body hairs; VBSLmin - minimal length of the ventral body hairs.

Measurements of the slide-mounted apterous viviparous females were performed by means of interactive measurement system Micro-Image (Olympus Optical Co. $\mathrm{GmbH}$ ). STATISTICA 8 version software (Statsoft 2007) was exploited for data analysis. Pearson's correlation coefficients were calculated to evaluate the correlation of morphometric characters with body length. Characters with strong $(|\mathrm{r}| \geq 0.70)$ statistically significant $(\mathrm{p}<0.05)$ correlation with body length were removed from the further analysis: BL ( $r=1.00)$, F3L ( $r=0.83)$, T3L ( $r=0.82)$, A2L ( $r=0.7)$, A3L ( $r=0.75)$, A4L $(r=0.71)$, A5L $(r=0.7)$. The remaining 12 characters were used for the forward stepwise discriminant analysis followed by canonical analysis, with sample collection number as the grouping variable, thus excluding information about the host plant from the analysis. Mean canonical scores of the first two canonical variables were represented as bivariate scatter plots, in order to show any clustering of samples.

Morphological characters that contributed most to canonical discrimination functions were evaluated as having potential for separation of taxa. An identification key was constructed based on these discrimination functions. The key was then tested on the 30 aphid samples that had not been used in its construction (listed in normal font in Table 1).

\section{Results}

\section{Partial sequences of mitochondrial COI gene}

Fifty partial COI sequences of $M$. cerasi and one of $M$. borealis from 11 countries were included in analysis. The alignment contained 616 bases in the final set with three variable sites, all of which appeared parsimony informative. The average base composition was $\mathrm{A}=34.0 \%, \mathrm{C}=12.7 \%, \mathrm{G}=12.3 \%$ and $\mathrm{T}=41.0 \%$. The overall transition/ transversion ratio $\mathrm{R}=1.221$ for all sites.

Five COI haplotypes were detected (Fig. 1): one for M. borealis, two for samples from $P$. cerasus and two for samples from P. avium (Table 2). Aphids collected from P. mahaleb, P. maackii and P. serrulata had the same haplotype (No. 3) as the majority 


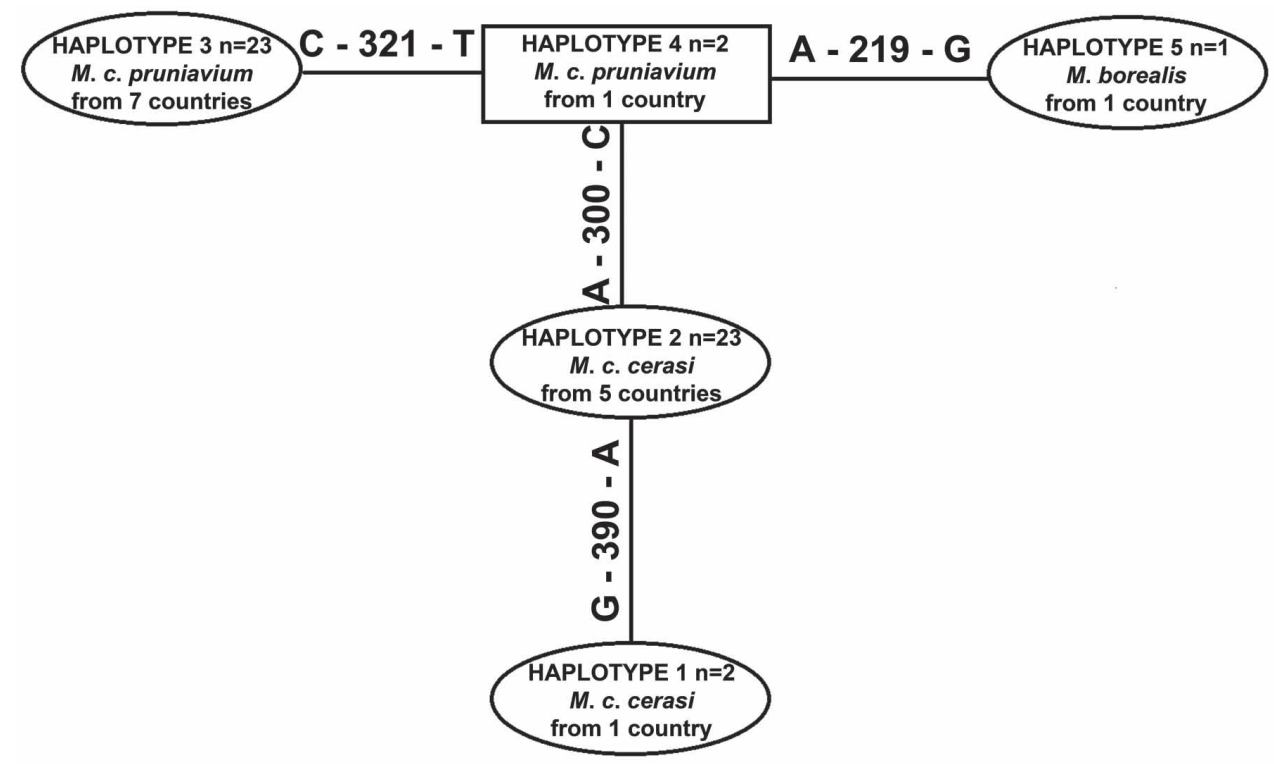

Figure I. Haplotype network (TCS 1.21 software: Clement et al. 2000) for COI fragment (616 positions in final set) haplotypes of Myzus cerasi and Myzus borealis. The haplotype with the highest outgroup probability is displayed as a square, while others are displayed as ovals. For sample information, see Table 2.

Table 2. COI haplotypes of three Myzus taxa revealed by construction of haplotype network. Sample numbers are the same as given in Table 1.

\begin{tabular}{|c|c|c|c|}
\hline $\begin{array}{l}\begin{array}{l}\text { Haplotype } \\
\text { number }\end{array} \\
\end{array}$ & \begin{tabular}{|l|}
$\begin{array}{l}\text { Number of } \\
\text { sequences }\end{array}$ \\
\end{tabular} & $\begin{array}{l}\text { Sequence } \\
\text { length (bp) }\end{array}$ & Sample numbers \\
\hline \multicolumn{4}{|c|}{ M. cerasi cerasi (collected from Prunus cerasus) } \\
\hline 1 & 2 & 616 & $13-33 ; 13-27$. \\
\hline 2 & 23 & 616 & $\begin{array}{l}08-6 ; 12-32 ; 12-176 ; 12-30 ; 08-18 ; \text { z12-122; 12-120; z12-112; 12-132; } \\
12-25 ; 12-43 ; 12-191 ; 12-203 ; 12-70 ; 12-72 ; 08-73 ; 13-83 ; 13-133 ; 11- \\
46 ; z 12-116 ; 12-37 ; 13-30 ; 13-57\end{array}$ \\
\hline \multicolumn{4}{|c|}{ M. cerasi pruniavium (collected from Prunus avium, except where otherwise noted) } \\
\hline 3 & 23 & 616 & $\begin{array}{l}\text { 11-10; 12-39; z12-110; 12-182; 12-104; 12-56; 12-83; 12-111; 12-199; } \\
\text { z12-90; z12-102; 12-48; 12-188; z12-113 (P. maackii); 04-49; 12-128; } \\
\text { 10-03; 13-60; 13-98; 13-97 (P. serrulata); 13-12; 13-119 (P. mahaleb); } \\
\text { z12-117 }\end{array}$ \\
\hline 4 & 2 & 616 & $11-27 ; 11-25$ \\
\hline \multicolumn{4}{|c|}{ M. borealis (collected from Galium rubioides) } \\
\hline 5 & 1 & 616 & $06-74$ \\
\hline
\end{tabular}

of samples from $P$. avium. COI haplotypes detected among samples from $P$. cerasus (No. 1 and 2) and the remaining Prunus species (No. 3 and 4) differed in the following nucleotide positions of 616 bp alignment: 300 (between No. 1-2 and No. 3-4), 321 (between No. 3 and No. 4) and 390 (between No. 1 and No. 2). The range of the intraspecific pairwise sample divergences (K2P model) was $0.0-0.5 \%$ (average $0.2 \%$ ), 
Table 3. Range of pairwise interspecific sample divergences of mitochondrial COI gene fragment (K2P model) for three species of Myzus (number of samples used is in parentheses).

\begin{tabular}{c|c|c}
\hline Species 1 & Species 2 & Range of divergence, \% \\
\hline M. cerasi (50) & M. borealis (1) & $0.2-0.5$ \\
\hline M. cerasi (50) & M. persicae (1) & $6.6-6.8$ \\
\hline M. borealis (1) & M. persicae (1) & 6.8 \\
\hline
\end{tabular}

whilst interspecific pairwise sample divergences between three species of $M y z u$ r ranged from 0.2 to $6.8 \%$ (Table 3 ).

The maximum parsimony (MP) analysis of partial COI sequences resulted in 930 equally parsimonious trees (length $=43, \mathrm{CI}=1.00, \mathrm{RI}=1.00)$. The $\mathrm{ML}$ tree (T92 model) showed similar topology, as did NJ (K2P distances) and BI (HKY+I+G model) analyses. $\mathrm{NJ}$, MP and ML bootstrap values over $50 \%$ together with BI posterior probabilities over 0.50 are given at respective nodes of the same tree in Fig. 2. Thus the M. cerasi samples form two major clades corresponding to two host-specific black cherry aphid taxa. One clade consists of all but two of the samples from $P$. avium, plus aphids collected from $P$. mahaleb, $P$. maackii and $P$. serrulata. The other clade contains all samples from $P$. cerasus and also includes the sample of $M$. borealis collected from Galium rubioides.

\section{Morphology}

When morphometric data of apterous viviparous females from 20 different geographical localities were subjected to discriminant analysis with sample collection number as the grouping variable, the first two canonical variates (Fig. 3) clearly separated sour cherry samples (COI haplotype No. 2) from those collected from sweet cherry (COI haplotype No. 3). Length of terminal process of antennal segment 6 (A6TPL), length of siphunculus (SL) and maximal length of the ventral body hairs (VBSLmax) appeared to be important predictors for separation of the two taxa (Table 4).

To discriminate between apterous viviparous females of host-specific black cherry aphid samples representing different clades in the haplotype network and the phylogenetic tree (Figs 1-2), the following linear discriminant function (LDF) was obtained: 3.924682×SL - 5.6667×A6TPL - 32.5504×VBSLmax + 1. Using this LDF, $97.37 \%$ individuals from the whole dataset were reclassified correctly into their a priori specified groups with host plant species as grouping variable, including $96.2 \%$ of apterous viviparous females from $P$. avium $(\mathrm{n}=79)$ and $98.6 \%$ from $P$. cerasus $(\mathrm{n}=73)$. The post hoc classification of the remaining thirty samples gave $92.37 \%$ correct specimen identification of $M$. cerasi cerasi $(\mathrm{n}=118)$ and $93.64 \%$ of $M$. cerasi pruniavium $(\mathrm{n}=110)$. The scatterplot of the mean LDF and body length values calculated for each of 30 samples representing different host specific subspecies of M. cerasi is shown in Fig. 4. The following key is therefore suggested for the identification of apterous viviparous females of the two subspecies of Myzus cerasi when sampled from winter hosts. 


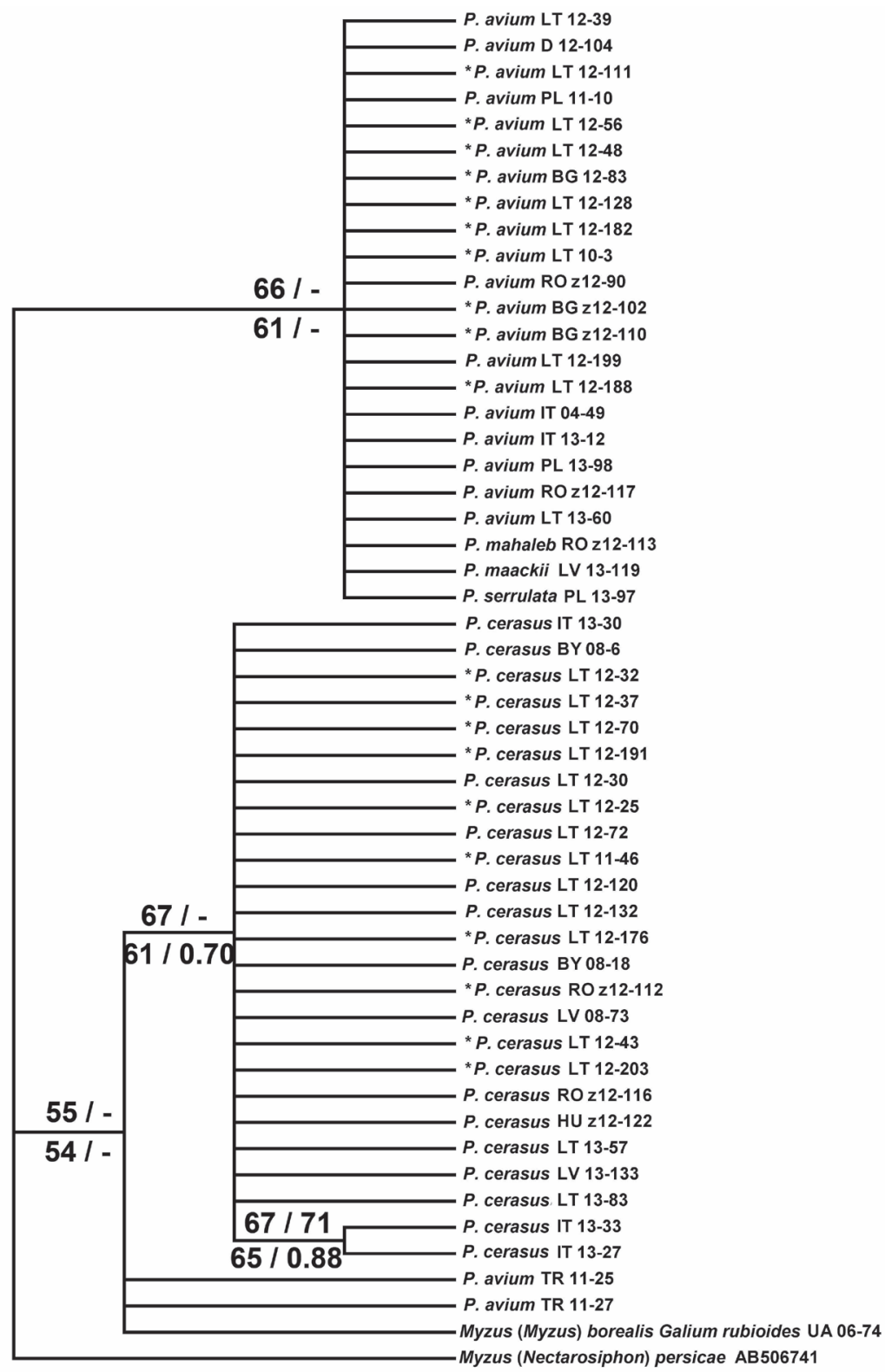

Figure 2. Maximum likelihood (ML) tree showing phylogenetic relationships among Myzus cerasi based on partial sequences of mitochondrial COI (616 positions in final set). Numbers above branches indicate support of $\mathrm{NJ}$ (left, > 50\%) and MP (right, > 50\%) bootstrap test with 1000 replicates, and numbers below branches indicate support of ML (left, $>50 \%$ ) bootstrap test with 1000 replicates and posterior probabilities of BI analysis (right, > 0.50). Samples used for the discriminant analysis with a priori specified group membership followed by the construction of identification key are asterisked $\left(^{*}\right)$. The remaining samples were used for the post hoc classification. Sample numbers are the same as given in Table 1, together with the abbreviated symbol of respective country BG - Bulgaria, BY - Belarus, D - Germany, HU - Hungary, IT - Italy, LV - Latvia, LT - Lithuania, PL - Poland, RO - Romania, TR - Turkey, UA - Ukraine. 


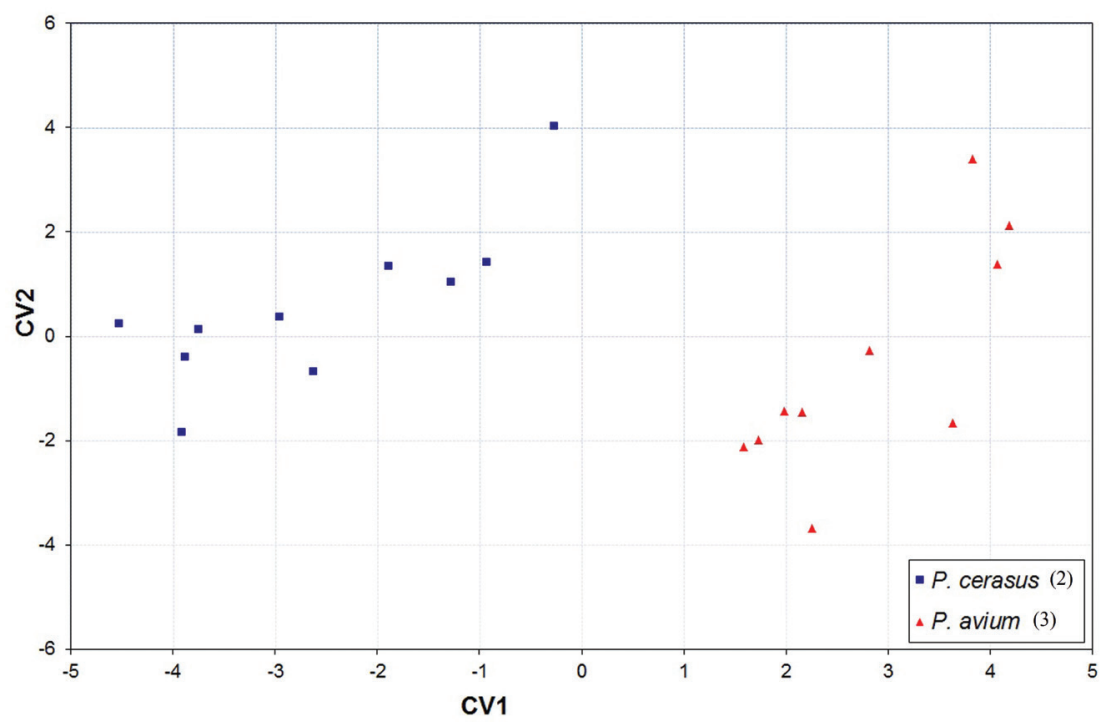

Figure 3. Plot of the mean scores of the first two canonical variates for 20 samples of Myzus cerasi (for specimen numbers per sample see Table 1). Samples cluster in accordance with winter host plant and COI haplotype (haplotype number is given in parentheses, see Table 2 for other haplotypes).

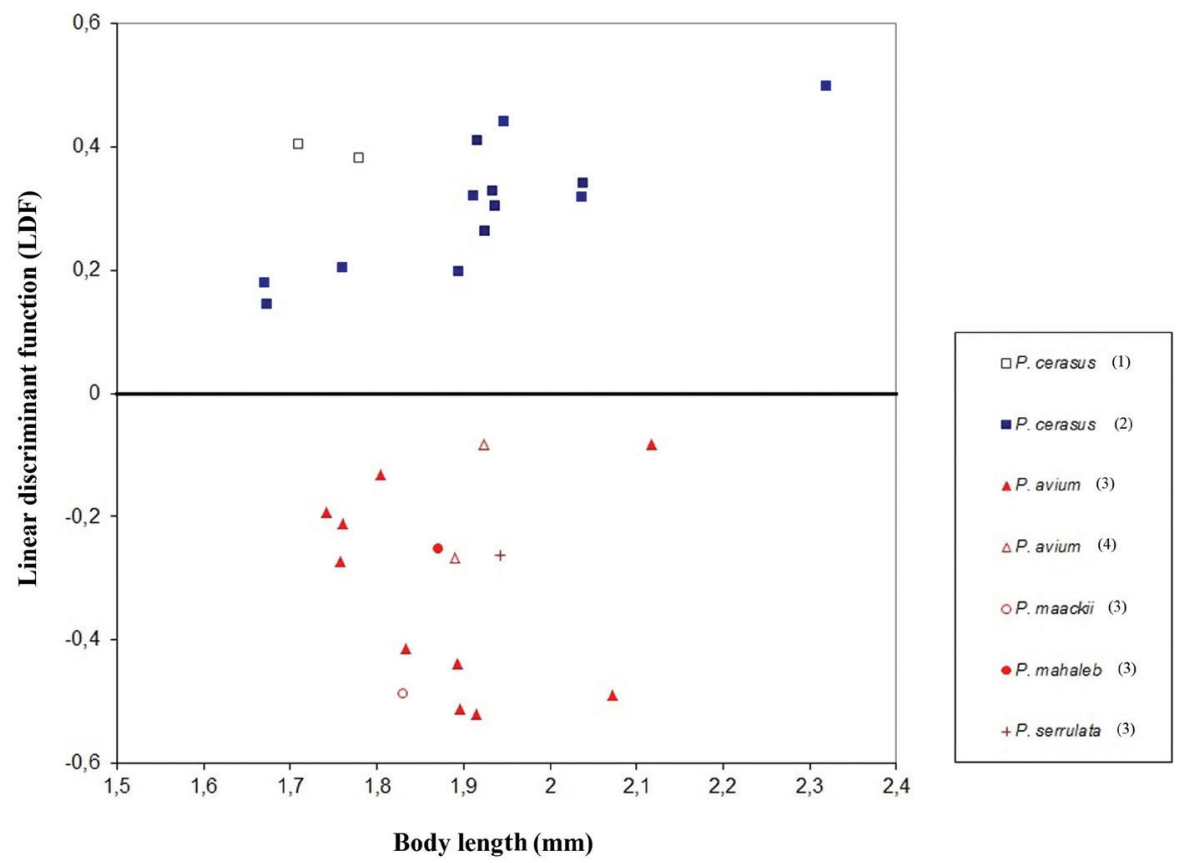

Figure 4. Plot of the mean scores of the individual LDF values (number of specimens per sample is given in Table 1) plotted against the mean body length for 30 samples of Myzus cerasi (normal font in Table 1) used to evaluate effectiveness of the eventual identification key. The icons are color-coded to match the COI haplotypes. Samples cluster in accordance with winter host plant and COI haplotype (haplotype number is given in parentheses, see Table 2 for haplotype information). 
Table 4. Contributions of 11 morphological characters to the canonical function discriminating 20 samples of M. cerasi. Character abbreviations are the same as in the text (Material and methods).

\begin{tabular}{l|c|c|c|c|c|c}
\hline & Wilks' Lambda & Partial Wilks' Lambda & F-remove & p-level & Toler. & 1-Toler. (R-Sqr.) \\
\hline A6TPL & 0.34 & 0.65 & 72.00 & 0.00 & 0.46 & 0.54 \\
\hline SL & 0.30 & 0.73 & 49.26 & 0.00 & 0.31 & 0.69 \\
\hline VBSLmax & 0.27 & 0.83 & 28.31 & 0.00 & 0.79 & 0.21 \\
\hline Bwant3 & 0.24 & 0.91 & 12.99 & 0.00 & 0.71 & 0.29 \\
\hline URL & 0.23 & 0.93 & 9.51 & 0.00 & 0.65 & 0.35 \\
\hline A6BL & 0.23 & 0.94 & 8.69 & 0.00 & 0.47 & 0.53 \\
\hline DT3L & 0.23 & 0.97 & 4.62 & 0.01 & 0.49 & 0.51 \\
\hline FF & 0.23 & 0.97 & 4.23 & 0.02 & 0.86 & 0.14 \\
\hline VBSLmin & 0.23 & 0.97 & 3.70 & 0.03 & 0.85 & 0.15 \\
\hline CL & 0.22 & 0.98 & 2.38 & 0.10 & 0.57 & 0.43 \\
\hline CW & 0.22 & 0.99 & 1.75 & 0.18 & 0.56 & 0.44 \\
\hline
\end{tabular}

Key to European subspecies of $M y z u s$ cerasi on Prunus (apterous viviparous females)

1 Value of LDF $[3.92 \times$ ( length of siphunculus) $-5.67 \times$ (length of terminal process of antennal segment 6$)-32.55 \times($ maximal length of the ventral body hairs $)+1]$ greater than zero. On $P$. cerasus (and sometimes on $P$. avium) M. c. cerasi - $\quad$ Value of LDF less than zero. On P. avium, P. maackii, P. mahaleb, P. serrulata... M. c. pruniavium

\section{Discussion and conclusions}

The combination of genetic distance evaluation with phylogenetic tree-building methods and multivariate analyses of morphometric data has been successfully applied to solve taxonomic problems in aphids, particularly in the genera Hyalopterus (Lozier et al. 2008), Pentalonia (Foottit et al. 2010), Aulacorthum and Neoaulacorthum (=Pseudomegoura) (Lee et al. 2011a). Based on the global data set, the average genetic divergence of COI barcode sequences between aphid species within the same genus was reported to be $5.84 \%$ (range $0.46-11.3 \%$ ), and that within species $0.05 \%(0.00-1.00 \%)$ (Foottit et al. 2008, Lee et al. 2011b). Interspecific divergence of six species representing three subgenera of Myzus calculated for COI barcode sequences was reported as ranging from 5.55 to $11.3 \%$ (Foottit et al. 2008). In comparison, partial COI sequences (GenBank, 1145 bp) of three Aphis fabae subspecies (A. f. fabae, GenBank accession numbers FJ965713, FJ965717-FJ965718; A. f. cirsiiacanthoidis, FJ965698-FJ965709; A.f. mordvilkoi, FJ965710-FJ965712) show values of genetic divergence (K2P model) ranging from 0.00 to $1.42 \%$ (Table 5). Therefore, the range of genetic divergence between the two clades of $M$. cerasi emerging in phylogenetic trees presented in this paper ( 0.0 to $0.5 \%)$ appears to be of intraspecific level. Based on the available COI data, black cherry 
Table 5. Pairwise sample divergences of 1145 bp mitochondrial COI gene fragment (K2P model) between three subspecies of Aphis fabae (number of sequences used is in parentheses).

\begin{tabular}{c|c|c}
\hline Subspecies 1 & Subspecies 2 & Mean and range of divergence, \% \\
\hline A.f.fabae (3) & A.f. cirsiiacanthoidis (12) & $1.2(0.97-1.42)$ \\
\hline A.f.fabae (3) & A.f. mordvilkoi (3) & $0.15(0.00-0.26)$ \\
\hline A.f. cirsiiacanthoidis (12) & A.f. mordvilkoi (3) & $1.05(0.97-1.15)$ \\
\hline
\end{tabular}

aphids inhabiting sour and sweet cherries should therefore still be regarded as a single species.

M. borealis is clearly closely related to $M$. cerasi and differs by only $0.2-0.5 \%$ of the COI sequences involved in the analysis. This suggests that it may also belong to the same species level taxon. More samples of $M$. borealis are needed to confirm this hypothesis. However, it should be noted that partial COI sequences of two biologically distinct Macrosiphum species, M. rosae (Linnaeus, 1758) and M. knautiae Holman, 1972 are very similar (Turčinavičienė and Rakauskas 2009), and low divergence levels have also been reported for Bursaphis species (Rakauskas et al. 2011) and adelgids (Žurovcová et al. 2010). It seems probable that in rapidly speciating aphid groups one may expect to find low levels of COI sequence divergence between taxa that are nevertheless functioning as distinct species.

\section{Acknowledgments}

This research was funded by a grant (No LEK-04/2012) from the Research Council of Lithuania. Kind assistance of S. Barbagallo and G. Cocuzza (Catania, Sicily), V. Zhuravlev (Kyiv, Ukraine), S. Buga (Minsk, Belarus), V. Spungéis (Riga, Latvia), A. Stalažs (Dobele, Latvia), M. Badini (Bagnolo Mella, Italy), A. A. Işıkber and M. M. Aslan, (Kahramanmaraş, Turkey) during field sampling in respective countries cannot be overestimated.

\section{References}

Barbagallo S, Cravedi P, Pasqualini E, Patti I (1997) Aphids of the principal fruit-bearing crops. Bayer S.p.A., Milan, 123 pp.

Basky Z, Szalay-Marszó L (1987) Study of isolation mechanisms in the Hyalopterus pruni and Hyalopterus amygdali complex. In: Holman J, Pelikan J, Dixon AFG, Weissman L (Eds) Population structure, genetics and taxonomy of aphids and Thysanoptera, Smolenice (Czechoslovakia), September 1985. Spb Academic Publishing, The Hague, 370-373.

Blackman RL, Eastop VF (1994) Aphids on the World's Trees: An Identification and Information Guide. CAB International, Wallingford, 1004 pp. www.aphidsonworldsplants.info 
Blackman RL, Eastop VF (2000) Aphids on the World's Crops: An Identification and Information Guide. $2^{\text {nd }}$ edn. J. Wiley \& Sons, Chichester, 466 pp.

Blackman RL, Eastop VF (2006) Aphids on the World's Herbaceous Plants and Shrubs. J. Wiley \& Sons, Chichester, Two volumes, 1439 pp. www.aphidsonworldsplants.info

Börner C (1943) Die Frage der züchterischen Bekämpfung der schwarzen Blattläuse der Kirsche. Zeitschrift für Pflanzenkrankheiten 53: 129-141.

Börner C (1952) Europae centralis aphides. Die Blättlause Mitteeuropas. Namen, Synonyme, Wirtspflanzen, Generationszyklen. Mitteilungen der Thüringischen Botanishen Gesselshaft 3: 1-488.

Cichocka E, Goszczynski W (2004) Black Cherry Aphid Myzus cerasi (F.) morphology. Aphids and Other Hemipterous Insects 10: 5-14.

Clement M, Posada D, Crandall KA (2000) TCS: a computer program to estimate gene genealogies. Molecular Ecology 9: 1657-1659. doi: 10.1046/j.1365-294x.2000.01020.x

Clements KM, Sorenson CE, Wiegmann BM, Neese PA, Roe RM (2000) Genetic, biochemical, and behavioral uniformity among populations of Myzus nicotianae and Myzus persicae. Entomologia Experimentalis et Applicata 95: 269-281. doi: 10.1046/j.1570-7458.2000.00666.x Clements KM, Wiegmann BM, Sorenson CE, Smith CF, Neese PA, Roe RM (2000a) Genetic Variation in the Myzus persicae Complex (Homoptera: Aphididae): Evidence for a Single Species. Annals of the Entomological Society of America 93: 31-46. doi: 10.1603/0013-8746(2000)093[0031:GVITMP]2.0.CO;2

Dahl ML (1968) Biologische und morphologische Untersuchungen über den Formenkreis der Schwarzen Kirschenlaus Myzus cerasi (F.) (Homoptera: Aphididae). Deutsche Entomologische Zeitschrift, Neue Folge 15: 281-312.

Depa L, Mroz E, Szawaryn K (2012) Molecular identity of Stomaphis quercus (Hemiptera: Aphidoidea: Lachnidae) and description of a new species. European Journal of Entomology 109(3): 435-444. doi: 10.14411/eje.2012.056

Eastop VF, Hille Ris Lambers D (1976) Survey of the World's Aphids. Dr. W. Junk b.v., Publishers, The Hague, 573 pp.

Favret C (2014) Aphid Species File. Aphid.speciesfile.org:TaxonName:26101 [accessed February 2014]

Fomicheva LI (1967) Biologija vishnevoi tli v sviazi s fenofazoi pitajushchego rastenija. Uchenye zapiski Moskovskogo gosudarstvenogo zaochnogo pedagogicheskogo instituta 16: 82-90. [In Russian]

Foottit RG, Maw HEL, von Dohlen CD, Herbert PDN (2008) Species identification of aphids (Insecta: Hemiptera: Aphididae) through DNA barcodes. Molecular Ecology Resources 8: 1189-1201. doi: 10.1111/j.1755-0998.2008.02297.x

Foottit RG, Maw HEL, Pike KS, Miller RH (2010) The identity of Pentalonia nigronervosa Coquerel and P. caladii van der Goot (Hemiptera: Aphididae) based on molecular and morphometric analysis. Zootaxa 2358: 25-38

Gruppe A (1988a) Elektrophoretische untersuchungen zur Unterscheidung der Subspezies von Myzus cerasi F. (Hom., Aphididae). Journal of Applied Entomology 105: 460-465. doi: 10.1111/j.1439-0418.1988.tb00210.x 
Gruppe A (1988b) Zur Unterscheidung der Subspezies von Myzus cerasi F. Mitteilungen der

Deutschen Gesellschaft für Allgemeine und Angewandte Entomologie 6: 568-572.

Gruppe A (1989) Möglische Ursachen der Resistenz von Kirschen (Prunus spp.) gegen Myzus

cerasi F. (Hom., Aphididae). Journal of Applied Entomology 108: 72-79. doi: 10.1111/ j.1439-0418.1989.tb00435.x

Gruppe A (1990) Untersuchungen zur Bedeutung von Ameisen für die Entwicklung und Ausbreitung der Schwarzen Kirschenblattlaus Myzus cerasi F. (Hom., Aphididae). Zeitschrift für Pflanzenkrankheiten und Pflanzenschutz 97: 484-489.

Hall TA (1999) BioEdit: a user-friendly biological sequence alignment editor and analysis program for Windows 95/98/NT. Nucleic Acids Symposium 41: 95-98.

Heinze K (1961) Systematik der mitteleuropäischen Myzinae mit besonderer Berücksichtigung der im Deutschen Entomologischen Institut befindlichen Sammlung Carl Börner (Homoptera: Aphidoidea - Aphididae) III. Beitrage zur Entomologie 11: 24-96.

Holman J (2009) Host plant catalog of aphids - Palaearctic region. Springer, Berlin, 1216 pp. doi: 10.1007/978-1-4020-8286-3

Karczewska M (1970) Z badan nad biologia mszycy wisniowo-przytuliowej-Myzus cerasi (F.) na wisni. Polskie Pismo Entomologiczne 40: 345-359.

Lampel G, Meier W (2007) Hemiptera: Sternorrhyncha - Aphidina. 2: Aphididae. Fauna Helvetica 16: 1-523.

Lee W, Kim H, Lee S (2011a) A new aphid genus Neoaulacorthum (Hemiptera: Aphididae: Macrosiphini), determined by molecular and morphometric analyses. Bulletin of Entomological Research 101: 115-123. doi: 10.1017/S0007485310000350

Lee W, Kim H, Lim J, Choi HR, Kim Y, Kim YS, Ji JY, Foottit RG, Lee S (2011b) Barcoding aphids (Hemiptera: Aphididae) of the Korean Peninsula: updating the global data set. Molecular Ecology Resources 11: 32-37. doi: 10.1111/j.1755-0998.2010.02877.x

Lozier JD, Foottit RG, Miller GL, Mills NJ, Roderick GK (2008) Molecular and morphological evaluation of the aphid genus Hyalopterus Koch (Insecta: Hemiptera: Aphididae), with a description of a new species. Zootaxa 1688: 1-19.

Miyazaki M (1971) A revision of the tribe Macrosiphini of Japan (Homoptera: Aphididae, Aphidinae). Insecta Matsumurana 34(1): 1-247.

Osiadacz B, Halaj R (2010) Systematic Review of Aphids (Hemiptera: Sternorrhyncha: Aphidomorpha) of Poland with Host Plant Index. Silesian Natural History Monographs 1: 1-191.

Pokrovskyj SV (1932) Opyt iskustvennogo zarazhenija razlichnych vidov Galium vishnevoj tlej Myzus cerasi Fabr. Zapiski bolshevskoi biologicheskoi stancii 5-6: 88-90. [In Russian]

Posada D (2008) jModelTest: Phylogenetic Model Averaging. Molecular Biology and Evolution 25: 1253-1256. doi: 10.1093/bioinformatics/14.9.817

Rakauskas R (1984) Biologija i ekologija vishnevoj tli v Litovskoi SSR. Trudy Akademii Nauk Litovskoi SSR, Serija Biologija, 4: 80-87. [In Russian]

Rakauskas R, Turčinavičienė J, Bašilova J (2011) How many species are there in the subgenus Bursaphis (Hemiptera: Sternorrhyncha: Aphididae)? COI evidence. European Journal of Entomology 108: 469-479. doi: 10.14411/eje.2011.060

Rakauskas R, Havelka J, Zaremba A (2013) Mitochondrial COI and morphological specificity of the mealy aphids (Hyalopterus spp.) collected from different hosts in Europe (Hemip- 
tera, Aphididae). In: Popov A, Grozeva S, Simov N, Tasheva E (Eds) Advances in Hemipterology. ZooKeys 319: 255-267. doi: 10.3897/zookeys.319.4251

Remaudière G, Remaudière M (1997) Catalogue of the World's Aphididae (Homoptera Aphidoidea). INRA Editions, Paris, 473 pp.

Ronquist F, Huelsenbeck JP (2003) MRBAYES 3: Bayesian phylogenetic inference under mixed models. Bioinformatics 19: 1572-1574. doi: 10.1093/bioinformatics/btg180

Ross WA (1918) The black cherry aphis. Annual Report of the Entomological Society of Ontario 36: 59-68.

Shaposhnikov GKh (1972) Podotriad Aphidinea - Tli. In: Nasekomye i kleshchi - vrediteli selskochoziaystvennych kultur. Nauka, Leningrad, 149-189. [In Russian]

StatSoft, Inc. (2007) STATISTICA for Windows (Computer program manual). Tulsa, USA.

Tamura K, Peterson D, Peterson N, Stecher G, Nei M, Kumar S (2011) MEGA5: Molecular Evolutionary Genetics Analysis using Maximum Likelihood, Evolutionary Distance, and Maximum Parsimony Methods. Molecular Biology and Evolution 28: 2731-2739. doi: $10.1093 / \mathrm{molbev} / \mathrm{msr} 121$

Turčinavičienė J, Pedersen BV, Rakauskas R (2006) Phylogenetic relationships in the "grossulariae"species group of the genus Aphis (Hemiptera: Sternorrhyncha: Aphididae): Molecular evidence. European Journal of Entomology 103: 597-604.

Turčinavičienė J, Rakauskas R (2009) Macrosiphum on Knautia in central Europe - molecular data support the synonymy of $M$. silvaticum and M. knautiae (Hemiptera Aphididae). Redia 92: 105-109.

Valenzuela I, Hoffmann AA, Malipatil MB, Ridland PM, Weeks AR (2007) Identification of aphid species (Hemiptera: Aphididae: Aphidinae) using a rapid polymerase chain reaction restriction fragment length polymorphism method based on the cytochrome oxidase subunit I gene. Australian Journal of Entomology 46: 305-312. doi: 10.1111/j.14406055.2007.00615.x

Vereshchagina VV (1966) Vishnevaja tlia Myzus cerasi Fabr. na chereshne i borba s nej v Moldavii. Trudy Moldavskogo nauchno-issledovatelskogo instituta sadovodstva, vinogradarstva i vinodelija 13: 53-57. [In Russian]

Voronova NN, Kurchenko VP, Buga SV (2011) Podbor molekuliarno-geneticheskich markerov dlia vidovoj diagnostiki tlej i postrojenija filogeneticheskich sistem. Trudy Belorusskogo Gosudarstvennogo Universiteta 6: 181-192. [In Russian]

Wimshurst FM (1925) The cherry black fly (Myzus cerasi). Bulletin of Entomological Research 16: 85-94. doi: 10.1017/S0007485300056182

Žurovcová M, Havelka J, Starý P, Věchtová P, Chundelová D, Jarošová A, Kučerová L (2010) "DNA barcoding" is of limited value for identifying adelgids (Hemiptera: Adelgidae) but supports traditional morphological taxonomy. European Journal of Entomology 107: 147-156. doi: 10.14411/eje.2010.020 